\title{
Identifying and Reducing the Health and Safety Impacts of Fuel-Based Lighting
}

\author{
Evan Mills, Ph.D. \\ Senior Scientist \\ Lawrence Berkeley National Laboratory \\ MS 90-2058 \\ Berkeley, CA 94720 USA
}

\begin{abstract}
The 1.3 billion people around the world who earn approximately one dollar per day pay a much higher percentage of their income for low-quality and polluting fuel-based illumination than those who have regular access to electric lighting. This inequity is compounded by adverse health and safety issues including: burns; indoor air pollution; poisoning due to accidental ingestion of kerosene fuel by children; compromised visual health; maternal health issues; and reduced service in health facilities illuminated solely or sporadically with fuel-based lighting. This article compiles and synthesizes information on the health and safety impacts of fuelbased lighting from 135 reports spanning 33 countries. Energy efficient, off-grid lighting solutions offer the most promising and scalable means to eliminate adverse health outcomes, while lowering lighting costs and reducing greenhouse-gas emissions. This article suggests next steps and policy options to improve the lives of people who depend on off-grid lighting services. Strategies seeking the greatest possible benefit should target the most impacted geographical and demographic user groups. Examples include: improved illumination in healthcare facilities; and the promotion of safe and efficient lighting systems where housing is dense and poorly defended from fire and where fuel adulteration is common. Because women and children are disproportionately impacted, improved lighting technologies for use by these groups will yield particularly significant health benefits.
\end{abstract}




\section{Context}

Approximately 1.3 billion people throughout the developing world (one-fifth of humanity), lack access to electricity and rely instead on fuel-based lighting (IEA 2014). ${ }^{1}$ Uncounted businesses also find themselves in the same situation, and additional users on the electric grid face routine outages or energy costs forcing reversion to fuel-based light sources. Today, more people than the world's population at the time Edison introduced electricity spend nearly USD 40 billion annually (100 times the cost of an equal amount of electric light) to operate highly inefficient lamps (Mills 2005). Lighting fuels are burned largely indoors and in close proximity to people, raising the question of more direct health and safety risks. Fuel-based lighting also contributes to climate change-itself a health and safety risk and compounder of poverty-by releasing substantial amounts of greenhouse-gas emissions (Mills 2005) and black carbon (Lam et al., 2012a).

Many fuels are used to generate light, including kerosene, ${ }^{2}$ propane, diesel, candles and a variety of bio fuels. Quantifying health impacts is of critical importance. Adverse health effects are recognized (Baker and Alstone 2011) but specific data and statistical indicators are rarely used in making the business case for alternatives. Improved information on current risks and potential health benefits of alternatives could also help identify and prioritize policy and market-based initiatives to replace fuel-based lighting with grid- and grid-independent alternatives powered by electricity.

The toxicity of lighting fuels has long been established within the medical literature (Pattle and Cullumbine 1956). For example, direct exposure of kerosene is reported to have a wide range of consequences, including chemical pneumonia from ingestion, drying of skin and dermatitis from skin contact, symptoms consistent with CNS depression (e.g. headache, vertigo) from inhalation, neuralgia, memory loss, and effects on blood, kidney, and respiratory function (Gad and Pham 2014). Kerosene contains known carcinogens such as benzene (American Cancer Society 2006) and probable ones such as formaldehyde (US EPA 2012), but studies have not focused on the cancer risks associated with indoor concentrations resulting from combustion in lanterns. Complicating such assessments, the composition of kerosene varies by refiner.

Kerosene is the most common fuel used for lighting in most countries (UNEP 2013), although candles are dominant in some areas. The use of kerosene for lighting is far more common than as a "clean" primary fuel for cooking, and combustion in stoves is far more complete, producing fewer particulate emissions per unit of fuel burned than when burned in lanterns. Kerosene is a primary cooking fuel among only four percent of urban populations and two percent of rural populations in less-developed countries (Legros et al. 2009).

\section{Scope and Review Methods}

\footnotetext{
${ }^{1}$ This article was also published in report form by UNEP (Mills 2014a).

${ }^{2}$ Common synonyms for kerosene include paraffin, no. 1 oil, coal oil, and lamp oil.
} 
Documentation of off-grid lighting risks is far more extensive than typically cited in the energy and development literature, yet less extensive and academically rigorous than that of other energy-related risks such as those from cooking with solid fuels. Assembling a comprehensive picture of the existing knowledge requires assessing a broader range of sources than found in peer-reviewed scientific literature, including news reports, informal reports, and other documents.

This body of literature paints a detailed picture of multiple risks, including: unhealthful indoor air quality, injuries, poisonings, and compromised visual health. Moreover, the low quality of fuel-based illumination has negative impacts on the delivery of healthcare in poorly lit facilities. Violence against women is also inversely correlated with light availability. Few prior efforts (Mills 2012; Lam et al. 2012b) have been made to synthesize or conduct a meta-analysis of the literature and reported data. This article provides the broadest review to date, comprising 135 reports of health issues related to off-grid lighting spanning 33 countries (Table 1). Underpinning the summary provided in this report, a database with additional detail has been posted online. ${ }^{3}$

While the source material varies widely, the base of evidence for lighting-related health impacts is firmly rooted in the peer-reviewed literature. Peer-reviewed studies include field reports (e.g., burns and accidental kerosene ingestion) as well as lab-based studies (e.g., pertaining to indoor air pollution from fuel-based lighting). The majority of relevant peer-reviewed studies are authored by medical professionals studying outcomes for patients in individual hospitals. While hospital reports provide a measure of risk prevalence, they capture only a small subset of impacts, especially in developing countries where hospitals are often inaccessible or injuries otherwise go unreported. Also, hospital records can attribute lighting to acute impacts, such as injuries (e.g., burns, poisonings), but not to disease from chronic exposures (e.g., poor indoor air quality). Some topics, such as house fires, are described primarily in grey-literature studies by local NGOs or news reports.

${ }^{3}$ Online database of health-related impacts from kerosene lighting. https://docs.google.com/a/lbl.gov/spreadsheet/ccc?key=0Avq_VXuy99CEdFVMaHJySWVsNnVvZkF2Nm4tN2pqMXc\#gid=0 
Table 1. Summary of reports on health and safety incidents related to fuel-based lighting.

\begin{tabular}{|c|c|c|c|c|}
\hline $\begin{array}{c}\text { Type of } \\
\text { incident or } \\
\text { impact }\end{array}$ & $\begin{array}{c}\text { Number } \\
\text { of } \\
\text { reports }\end{array}$ & $\begin{array}{c}\text { Number } \\
\text { of } \\
\text { countries }\end{array}$ & Countries & Type of source \\
\hline $\begin{array}{l}\text { Structure } \\
\text { fires }\end{array}$ & 23 & 11 & $\begin{array}{l}\text { Bangladesh, China, India, Liberia, } \\
\text { Namibia, Nepal, Philippines, Senegal, } \\
\text { South Africa, Tanzania, Uganda } \\
\end{array}$ & $\begin{array}{l}\text { Largely news reports, with some } \\
\text { NGO publications and databases }\end{array}$ \\
\hline $\begin{array}{l}\text { Kerosene } \\
\text { burns }\end{array}$ & 24 & 10 & $\begin{array}{l}\text { Bangladesh, India, Mozambique, Nepal, } \\
\text { Nigeria, Philippines, South Africa, Sri } \\
\text { Lanka, Uganda, Zimbabwe }\end{array}$ & $\begin{array}{l}\text { Largely peer-reviewed articles from } \\
\text { the medical literature }\end{array}$ \\
\hline $\begin{array}{l}\text { Kerosene } \\
\text { explosions }\end{array}$ & 23 & 6 & $\begin{array}{l}\text { India, Niger, Nigeria, Papua New Guinea, } \\
\text { Sierra Leone, South Africa }\end{array}$ & $\begin{array}{l}\text { Predominantly peer-reviewed } \\
\text { literature, with some government } \\
\text { studies and news reports }\end{array}$ \\
\hline $\begin{array}{l}\text { Kerosene } \\
\text { ingestion }\end{array}$ & 35 & 20 & $\begin{array}{l}\text { Antigua and Barbuda, Barbados, China, } \\
\text { Ghana, India, Iraq, Israel, Jamaica, } \\
\text { Jordan, Kenya, Libya, Malawi, Malaysia, } \\
\text { Nepal, Nigeria, Pakistan, Sierra Leone, } \\
\text { South Africa, Sri Lanka, Zimbabwe } \\
\end{array}$ & $\begin{array}{l}\text { Largely peer-reviewed articles from } \\
\text { the medical literature, as well as } \\
\text { NGO surveys }\end{array}$ \\
\hline $\begin{array}{l}\text { Indoor air } \\
\text { quality* } \\
\text { (laboratory } \\
\text { and field } \\
\text { studies) }\end{array}$ & 16 & 4 & Ghana, Malawi, Nepal, Philippines & Largely peer-reviewed literature \\
\hline $\begin{array}{l}\text { Visual } \\
\text { performance } \\
\text { or health }\end{array}$ & 8 & 7 & $\begin{array}{l}\text { Ethiopia, Ghana, Kenya, Nepal, Tanzania, } \\
\text { Thailand, Zambia }\end{array}$ & $\begin{array}{l}\text { Peer-reviewed literature, academic } \\
\text { reports, NGO reports }\end{array}$ \\
\hline $\begin{array}{l}\text { Women's } \\
\text { health } \\
\end{array}$ & 6 & 5 & $\begin{array}{l}\text { India, Nigeria, Sierra Leone, Tanzania, } \\
\text { Zambia }\end{array}$ & $\begin{array}{l}\text { Peer-reviewed literature and NGO } \\
\text { reports }\end{array}$ \\
\hline TOTAL & 135 & 33 & & \\
\hline
\end{tabular}

\section{Synthesis of Current Understanding}

The literature synthesized in this article provides a high-level, global picture of morbidity and mortality risks associated with fuel-based lighting:

- Fuel-based lighting is a significant cause of severe burn injuries, with particularly high death rates (24\% of those admitted to hospitals, on average) in cases where kerosene is adulterated with other fuels and results in explosions, and a $6 \%$ mortality rate in other cases. Where destructive house fires are involved, decimating the hard-earned wealth of uninsured poor people, the resulting poverty and deprivation from being homeless can lead to additional harms.

- Indoor pollutants from fuel-based lamps include concentrations of particularly unhealthful PM2.5 particles an order of magnitude higher than health guidelines. Correlations with cataract and tuberculosis have been observed, but require further study to confirm and quantify causal links to off-grid lighting. Risks from fuels other than kerosene have not been studied. 
- Unintentional ingestion of kerosene the leading cause of child poisoning in the developing world. It is typically the number-one cause of child poisoning in developing countries, with an average mortality rate of $7 \%$ for the studies reviewed.

- Illumination levels from fuel-based lanterns are only $1 \%$ to $10 \%$ of those recommended by lighting authorities in industrialized countries. Users complain of vision-related problems and eye irritation, but formal measures of health and welfare impacts are limited. Inadequate illumination in clinics creates visual performance challenges that impede the delivery of quality healthcare, and discourages patients from seeking care. Some reports detail the risks of adverse outcomes in clinics such as maternal and infant mortality as well as difficulties maintaining good sanitation, which can lead to increased incidence of infections.

- Existing data suggest that fuel-based lighting injuries and pollutant exposures disproportionately affect women and children.

- Replacing intrinsically dangerous fuel-based lighting with electric light sources is the most promising and scalable way to reliably eliminate these risks.

There are few large-scale or statistically representative assessments of health impacts associated with off-grid lighting. As described below, many studies report that accidental ingestion of kerosene is the primary case of child poisoning in the developing world. In South Africa, 79,750 very young children are estimated to unintentionally ingest kerosene each year (160 per 100,000; occurring in 3.6\% of all households) of which $60 \%$ develop a chemically induced pneumonia (Paraffin Safety Association 2004). Also in South Africa, over 200,000 people are estimated to be injured or lose property each year due to kerosene-related fires, or 400 per 100,000 (Paraffin Safety Association 2012a). Kimemia et al., (2014) estimate that 40\%, or 400 to 700 of all settlement fires in South Africa are attributed to candles, and $14 \%$ of burn injuries. In Bangladesh, kerosene lamps are responsible for $23 \%$ of infant burns (Mashreky et al. 2008), corresponding to about 17,000 annual injuries nationally. Three multi-year reviews of admissions to Nigerian hospitals attributed approximately $30 \%$ of all burn cases to kerosene lamp explosions (Asuquo et al. 2008; Oludiran and Umbese 2009; Olaitan et al. 2007). Even higher burn rates (approximately $40 \%$ of all burns) are attributed to kerosene lamps in Sri Lankan homes, with 150 to 200 lives lost annually, with a cost for associated medical care of USD $1 \mathrm{M}$ annually (Shepherd and Perez 2007).

A complex array of social, political, and behavioural factors contribute to the problem, including lack of product safety labelling or warnings, illiteracy (inability to receive communications about risk), overcrowding (contributes to rapid spread of fires and peoples' proximity to lantern emissions), corruption and fuel subsidies (resulting in fuel adulteration (Mills 2014c)), unsupervised children, poverty (inability to afford child-safe containers for fuels), cultural practices such as keeping lamps next to young children while they sleep, to ward off "evil spirits" (Mashreky et al. 2008), ineffective or counterproductive folk remedies (for example, inducing vomiting after kerosene ingestion which causes undesirable aspiration of kerosene into the lungs) (Azizi et al. 1994), and, unwillingness or inability to seek professional care following injuries. 


\section{Self-reported Risks and Symptoms}

Users of fuel-based lighting exhibit widely varying awareness of the risks. For example, a statistically representative survey of 3,300 fuel-based lighting users across five sub-Saharan African countries found $26 \%$ to express related health concerns (Baker and Alstone 2011). Within this group, perceived risk of fuel-based lighting on health varied widely: $57 \%$ in Zambia, 44\% in Kenya, 21\% in Tanzania, 14\% in Ghana, and 4\% in Ethiopia. Figure 1 summarizes the users' specific concerns.

\section{Health and safety risks perceived by fuel-based lighting users}

(Ethiopia, Ghana, Kenya, Tanzania, Zambia)

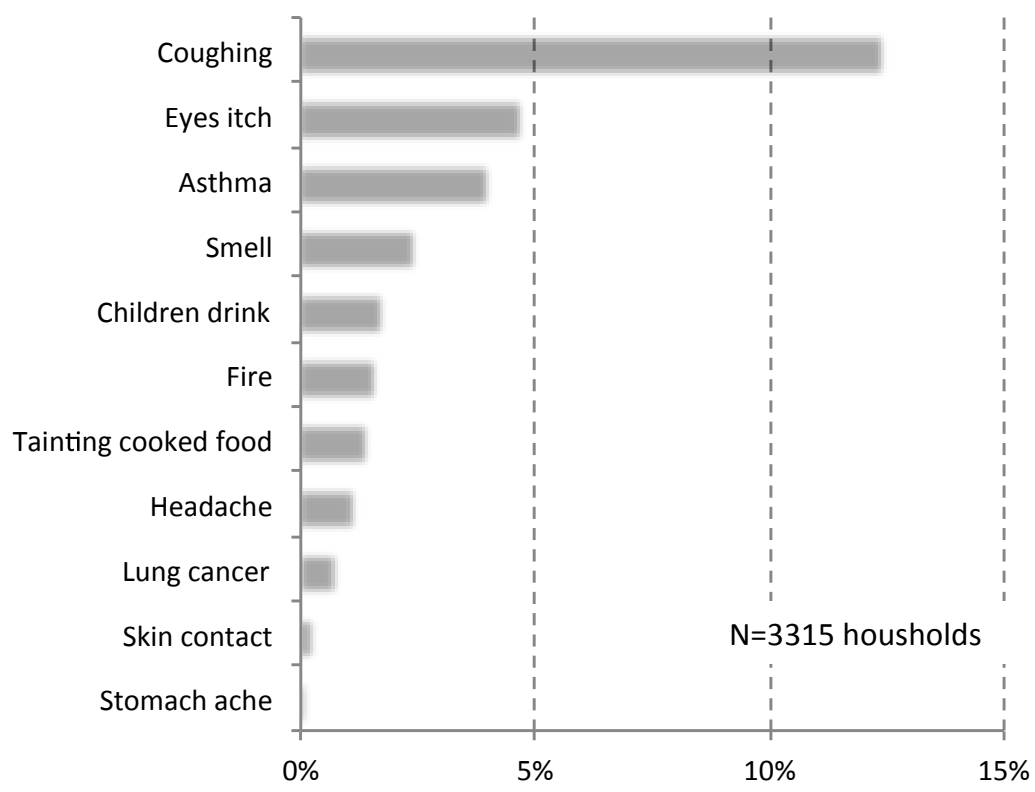

Figure 1. Perceived health consequences of fuel-based lighting and inadequate service levels. (Source: Baker and Alstone 2011)

In another proxy of user awareness, a study in the Philippines found that only $9 \%$ of users cited perceived safety and health benefits as a reason for seeking alternatives to fuel-based lighting (Planète d'Entrepreneurs 2011). The only demographic factor reported to correlate with reduced injury is income, with wealthier individuals using safer practices (Schwebel et al. 2009a).

The following sections provide further details, organized by type of health and safety risk.

\section{Burns}

There is no global estimate of burn-injuries attributable to fuel-based lighting. However, more than $95 \%$ of deaths worldwide from all types of burns occur in the low- and middle-income 
countries (WHO 2002a). The mortality rate is five times higher in low- and middle-income populations in Africa than in high-income countries in Europe (World Health Organization 2002a). In South-East Asia, the rate is 8.3-times greater than in Europe. The World Health Organization estimated global deaths from burns and smoke inhalation during structural fires were on the order of 322,000 in the year 2002, which Peck et al. (2008) refer to as likely a "gross underestimate." In an even lower estimate, the number of burns was placed at 195,000 for the year 2008 (World Health Organization 2012b).

Burns are a leading cause of injury among children, and fuel-based lighting is the primary cause among young children. ${ }^{4}$ In southern India, burns are the number-two cause of injury-related mortalities among children, just over half of which are due to lanterns $(9.3 \%$ of total injuryrelated mortalities) (Kanchan et al. 2009). A survey of 134 households in the Philippines found that $18 \%$ had experienced burns due to kerosene (presumably lighting plus cooking) (Planète d'Entrepreneurs 2011). Mashreky et al. (2008) found that burns caused by fuel-based lighting occur disproportionately more often for infants than do other causes of burns (Figure 2).

\section{Distribution of burn injuries by age group (Bangladesh)}

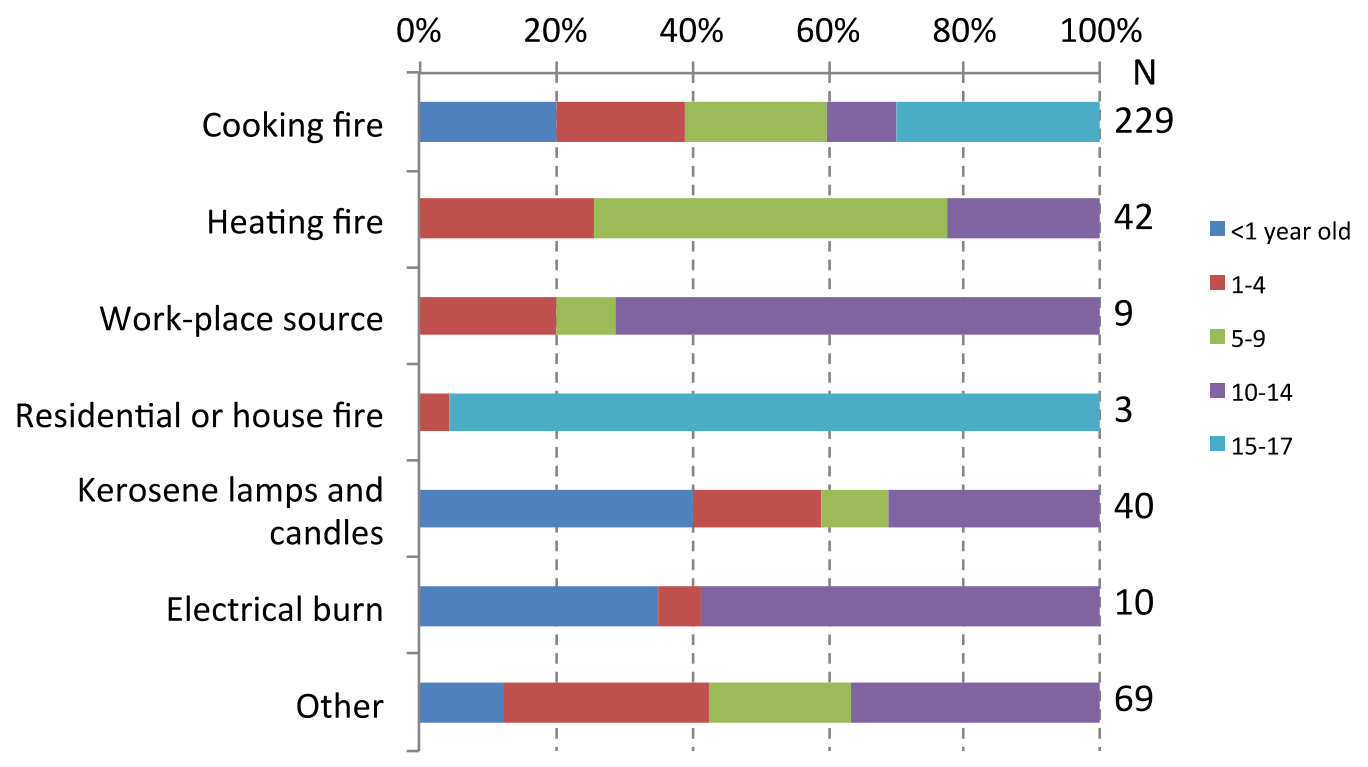

Figure 2. Infants incur about $40 \%$ of the burns caused by fuel-based lighting in Bangladesh, the leading causal factor for that age group in that country (adapted from Mashreky et al. (2008)).

Lighting-related burns can result from structural fires, direct contact with hot lamps or flames, and explosions due to the adulteration of kerosene with other fuels. While there is a wide range of fuel-based lantern types, the literature does not generally identify the type involved. Open-flame devices (kerosene wick lamps or candles) pose the greatest risk.

\footnotetext{
${ }^{4}$ See http://www.healthmetricsandevaluation.org/gbd/visualizations/gbd-cause-patterns
} 
Burn injuries are often followed by infection, and subsequently by disability and psychosocial trauma. Lighting-related burn injuries are pervasive in the developing world, with incidents documented in Bangladesh, China, India, Liberia, Mozambique, Namibia, Nepal, Niger, Nigeria, Papua New Guinea, the Philippines, Senegal, Sierra Leone, South Africa, Sri Lanka, Tanzania, Uganda, and Zimbabwe.

The publications reviewed here reflect a $6 \%$ weighted-average death rate from regular burns and $24 \%$ in the case of lantern explosions. It is important to reiterate that the literature is based primarily on studies of individuals admitted to hospitals, and thus reflects only a small subset of all cases that occur in the broader population. These cases tend to be particularly severe. For example, of the 1,368 cases studied by Jayaraman et al. (1993) one-third were fatal.

Statistics for burns caused by lighting fuels other than kerosene are rare. The Paraffin Safety Association of South Africa (2012), collected extensive data on injuries associated with lighting by candles. They find that candles - three-times more common than kerosene for lighting in South Africa (Statistics South Africa 2012b) - are implicated in one-third of burn injuries in the country, with $58 \%$ of the injuries involving males. Females are in the majority for the 0 - to 24 year age group. Elsewhere in sub-Saharan Africa, candles are used as a source of light in nonelectrified households by $79 \%$ in Zambia, $20 \%$ in Ethiopia, $19 \%$ in Tanzania, $18 \%$ in Ghana, and $10 \%$ in Kenya (Baker and Alstone 2011).

\section{Structure fires}

Over a century ago, large fires in China, displacing 1,000 families in one case, were traced to kerosene lamps imported from the United States of America. This problem was relayed by the U.S. President to Congress as a matter affecting foreign relations with China (Office of the President 1888). Many subsequent fires in residences in the developing world were caused by fuel-based lighting. When fires occur in informal settlements, slums or camps for displaced persons, they spread rapidly due to crowding and flammability of housing materials. Newspaper accounts report some very large fires, such as one affecting 3,000 people in a Philippine informal settlement in 2009, killing 16 (Daily Mail 2009). ${ }^{5}$ The former fire chief in Monrovia, Liberia notes the occurrence of an average of one candle-related "shack fire" every week (Dawson 2013).

Nearly 24,000 fires in informal housing settlements were recorded nationally in South Africa between 1998 and 2006, resulting in 1,088 deaths (Birkenshaw 2008). Swart (2012) estimates that $30 \%$ of shack fires in the country are started by candles. Kimemia et al., (2014) put the value at $40 \%$ of fires and $15 \%$ of burn injuries. A random sample of households in South Africa

\footnotetext{
${ }^{5}$ Other examples include fires destroying 200 homes in India in 2010 (Thaindian News 2010), and 1,500 homes - killing 15- in Bangladesh in March 2000 (Associated Press 2000). Refugee camps are also vulnerable, as in the case of a Nepali camp where 1,200 of 1,500 homes were burned by a fire suspected to have been started by a lantern, leaving 12,000 homeless (UCRI 2010). Slum fires are a routine occurrence.
} 
found that kerosene-related fires (presumably for cooking as well as lighting equipment) had occurred in $6.3 \%$ of all households (Matzopoulos et al. 2006). ${ }^{6}$

\section{Explosions resulting from the adulteration of kerosene with other fuels}

The adulteration of kerosene with gasoline or diesel fuel creates a volatile mix that can ignite and explode. ${ }^{7}$ The resulting injuries are severe, and often fatal. Some unscrupulous oil merchants adulterate kerosene with other fuels when they are even slightly less expensive, or during times of kerosene scarcity (Babalola and Ekiti 2011). Unintentional adulteration can also occur when end-users utilize the same containers for gasoline and kerosene or suppliers inadequately isolate or flush mixed-use pipelines or tanks. Given that individuals often purchase kerosene in small quantities, modest amounts of adulterated kerosene can be disseminated to large populations.

Reports of kerosene adulteration have emerged from India, Niger, Nigeria, Papua New Guinea, Sierra Leone and South Africa. Reports are most common in Nigeria (Lawal 2011). A report of kerosene adulteration that impacted 2,500 people, of which 368 (14\%) died, came from Nigeria's Edo region (Bernard 2011). In one household, 8 of 10 family members were killed (Ugburo et al. 2003). These incidents are frequent; long-term studies find chronically high rates of hospital admissions due to explosions in Nigeria. One event in India (Gupta et al. 1998) affected 303 people. With only 10 beds available in the local hospital's emergency burn unit, many patients were turned away or referred to distant hospitals. In two cases from India, 48,000 and 72,000 litres of fuel were adulterated in the same month (The Telegraph 2011a; 2011b).

Table 2. Illustrative "Epidemics of Kerosene Disasters" caused by fuel adulteration.

\begin{tabular}{|l|l|c|l|}
\hline Year & Location & $\begin{array}{c}\text { People } \\
\text { injured/killed } \\
\text { [Female: Male] }\end{array}$ & Source \\
\hline 1984 & Lagos, Nigeria & $53 / 30[1.9: 1]^{*}$ & Grange et al. (1988) \\
\hline 1994 & Rajasthan, India & $303 / 37$ & Gupta et al. (1996) \\
\hline 2001 & Lagos, Nigeria & $116 / 18[1.5: 1]$ & Oduwole et al. (2003) \\
\hline 2001 & Lagos, Nigeria & $59 / 35[1.3: 1]$ & Ugburo et al. (2003) \\
\hline 2001 & Madang, Papua New Guinea & $38 / 5$ & National Disaster Management Office (2001) \\
\hline 2004 & Edo State, Nigeria & $2500 / 368$ & Bernard (2011) \\
\hline 2007 & Delta State, Nigeria & 22 & Onoyume et al., (2007) \\
\hline 2011 & Port Harcourt, Nigeria & $1 / 5$ & Nigeria News (2011) \\
\hline 2011 & Edo State, Nigeria & $1 / 8$ & Daily Independent (2011) \\
\hline 2011 & Duhbri, India & $62 / 8$ & The Telegraph (2011) \\
\hline 2012 & Edo and Delta States, Nigeria & $11 / 11$ & Tamuno (2012) \\
\hline
\end{tabular}

* Ratio in month of burn disaster (March). Ratio 1:1 in earlier periods.

\footnotetext{
${ }^{6}$ One fire there, attributed to a single candle, killed two people while destroying 500 homes and leaving 2,000 people homeless (The Mercury 2010).

${ }^{7}$ The lowest temperature at which kerosene vaporizes and forms an ignitable mixture in air is at least 38C, which drops to about $5 \mathrm{C}$ with only $10 \%$ adulteration with gasoline (Shepherd and Perez 2007). Explosions occur most easily when lanterns are refueled while lit, and the evaporating fumes ignite.
} 
Three multi-year reviews at Nigerian hospitals attributed around $30 \%$ of all burn cases to kerosene fuel explosions (stoves plus lanterns) (Dongo et al. 2007; Asuquo et al. 2008; Olaitan et al. 2007). In the latter study, injuries to females outnumbered those to men by nearly $3: 1$. In another study (covering just one month), $96 \%$ of burn admissions were due to kerosene device explosions. Of those burned, $62 \%$ were children and $60 \%$ were female; the average body-area burned was $24 \%$ (with a $44 \%$ overall mortality rate) (Oduwole et al. 2003). The month covered by the study followed the discovery that a petroleum storage depot deliberately adulterated the kerosene before sale. Oludiran and Umebese (2009) found that $52 \%$ of children (half below the age of 3) admitted to a hospital for burns received their injuries from exploding kerosene lanterns or stoves, with burns covering between $6 \%$ and $50 \%$ of body area. Oduwole et al. (2003) observed $100 \%$ mortality for cases with burns covering more than $18 \%$ of total body area. Another author found that half the admissions were children, with a nearly 6-fold increased admission rates at one hospital following an incident in 1984, with $47 \%$ mortalities versus none for burns in the same month, prior year (Grange et al. 1988).

\section{Indoor Air Pollution}

Poor indoor air quality in developing countries creates a large societal burden, both economic and humanitarian (Zhang and Smith 2007). Fuel-based lanterns are located in close proximity to users; they emit small-diameter particles that can be inhaled deeply into the lungs. Other emissions resulting from burning kerosene include carbon monoxide, carbon dioxide, sulphur dioxide, nitrogen dioxide, formaldehyde, and various volatile organic carbons (VOCs). As of 2010, an estimated 2.6 to 4.4 million deaths (Lim et al., 2012) occur each year from poor indoor air quality associated with cooking with solid fuels in the developing world. These deaths are sometimes incorrectly attributed to lighting; no such estimate has been in fact been made and the risks are substantially lower (Lam 2013).

Inhalation of particulates resulting from indoor combustion can cause a range of adverse health effects (Bai et al. 2007; Pokhrel et al. 2009; Lam et al. 2012b). Among the potentially harmful effects are impairment of ventilatory function (Behera et al. 1991) and a higher incidence of acute lower respiratory infection among those using kerosene and bio fuels (Sharma et al. 1998). One of the potential consequences of indoor pollutants from kerosene lanterns is tuberculosis, a major health issue in the developing world. In the only study to explore the role of lighting, researchers found the odds of having tuberculosis in Nepal were more than ninetimes greater for women using kerosene lamps for indoor lighting than those using electric light (Pokhrel et al. 2010). The authors did not have detailed measures of lighting behaviours that may have contributed to this risk but note that kerosene lamps may burn less efficiently, for longer hours, and release emissions closer to users than do stoves.

Van Vliet et al. (2013) offers one of the only studies to measure lighting-related particulates in actual occupied homes, and found a significant contribution from kerosene lanterns above that traced to biofuels used for cooking. Measurements by Apple et al. (2010) demonstrated that night vendors who use a single simple wick lamp in simulated high-air-exchange market kiosks will likely be exposed to dangerous PM2.5 concentrations that are an order of magnitude 
greater than ambient health guidelines (WHO 2006). Thanks to more efficient combustion, using a hurricane lamp will reduce exposure to PM2.5 and PM10 concentrations by an order of magnitude compared to a simple wick lamp. There are no known standards regulating emissions of or exposure to particulates produced from fuel-based lanterns. It should be noted that the particulate emissions of kerosene lanterns (and likely candles (Zai et al. 2004)) also represent significant amounts of black carbon, strongly implicated in climate change (Lam et al. 2012a). Estimates of ultimate indoor exposure to total PM emissions found that those of kerosene lamps were approximately three times that of candles (Fan and Zhang 2001).

Studies to date on the indoor air quality impacts associated with lighting fuels have focused on kerosene. Little assessment has been made of health issues associated with lighting-related uses of certain other fuels, including candles, diesel, animal and vegetable oils, dung, or fuel wood. Fine et al. (1999) identified approximately 150 organic compounds present in candle smoke and unburned candle wax. Concerns in addition to fuel-combustion products are wicks made with lead cores as a stiffening agent ${ }^{8}$ and lantern mantles made with radioactive thorium, neither of which are accompanied with safety warnings or disposal instructions when sold in the developing world. Burning candle wicks have been shown to yield indoor concentrations of lead above ambient air standards and workplace standards (Wasson et al. 2002).

While indoor particulate matter concentrations from cook stoves have been extensively studied, characterization of particulate concentrations from fuel-based lighting has received minimal attention (Schare and Smith (1995); Fan and Zhang (2001), Apple et al., (2010), and Van Vliet et al., (2013). This is unfortunate, given that fuel-based lighting and dirty cooking fuels often exist in the same households and the relative effects need to be isolated. Lighting combustion is generally poorer than in liquid-fuelled stoves; the mix of particle types and sizes will vary by fuel and even lantern type. According to an estimate by Poppendieck et al., human inhalation of particulate matter from simple wick lamps is about 5-times less than that of cook stoves, yet is also about 5-times more than from ambient air (2010). ${ }^{9}$ Lam (2013) found the gap between lighting and cooking to be smaller than this. Fullerton et al. (2009) found higher levels of particulate matter associated with macrophage cells in people living with kerosene lamps, particularly simple wick-based lamps but also with hurricane lanterns and candles, which have particularly incomplete combustion.

\section{Unintentional Poisoning}

Unintentional poisoning resulting from the drinking of kerosene has been reported in Antigua and Barbuda, Barbados, China, Ghana, India, Iraq, Israel, Jamaica, Jordan, Kenya, Libya, Malawi, Malaysia, Nepal, Niger, Nigeria, Pakistan, Sierra Leone, South Africa, Sri Lanka, and Zimbabwe.

\footnotetext{
8 Outlawed in the USA since 2003.

${ }^{9}$ Per Poppendieck et al., for outdoor-ambient conditions and indoor conditions with lamps, inhalation mass (versus absorbed dose) is based on the product of average inhalation rate $4.5 \mathrm{~L} / \mathrm{min}$, exposure duration ( 2.5 hours per day for lamps, $10 \mathrm{hours}$ for ambient), and average measured particle concentration from Apple et al. (2010). Values for cooking were based on multiple filter measurements performed over periods of 8 to 24 hours, with cooking occurring intermittently during those periods, assuming all particle mass was from stoves and that the occupant was inside while the cooking fuel was burning, evaluated at the aforementioned breathing rate.
} 
Having an appearance and density similar to that of water and frequently stored in unsecured ordinary beverage containers, kerosene is readily ingested by children. This risk is ironically compounded by lack of adequate illumination. In all 36 cases (51\% of all child poisonings) reported in a Malaysian study (Azizi et al. 1994), kerosene was kept in a soft-drink bottle, typically on the kitchen floor. Most studies on poisonings in the developing world (such as Osaghae and Sule 2013) have identified kerosene to be a leading cause of poisoning in children, ranging from $25 \%$ to $65 \%$ of all cases in the literature reviewed here.

According to one source (Nisa et al. 2010), ingesting as little as one millilitre of kerosene can cause complications, while ten millilitres can be fatal. Common complications include respiratory effects and pulmonary damage. Additional impacts include gastrointestinal irritation, fever, central nervous system impairment, fever, myocarditis and leukocytosis. A broader literature review identified that the chemical form of pneumonia occurs in $12 \%$ to $40 \%$ of the cases (Carolissen and Matzopoulos 2004). ${ }^{10}$ Sufficient dosages can lead to coma and death. Among the particularly high mortality levels, a rate above $5 \%$ was observed in a six-year hospital study in Nigeria (Belonwu and Adeleke 2008). There was a 7\% average death rate (weighted by number of deaths) across 21 studies reporting mortality rates, with a large variance in outcomes across studies.

\section{Illuminance Levels and Compromised Visual Performance}

The illuminance levels recommended by professional illuminating engineering societies for electric lighting are 10 to 100 times greater than the levels provided by fuel-based lanterns (Mills and Borg 1999). ${ }^{11} \mathrm{~A}$ study of home lighting in a rural Nepali village led to recommended levels in the 5 to 15 lux (lumens per square meter) range for general-purpose lighting, primarily for cooking and socializing, and 25 lux for reading (Bhusal et al. 2007). These levels are still below the levels recommended by illumination engineering societies, but higher than the levels typically provided by fuel-based lighting. The dominant fuel type in the Nepali study was burning jharro (resin soaked pine sticks)..$^{12}$ Interviews of a small number of fuel-based lighting users in the field indicate that night vendors find the illuminance levels from fuel-based lanterns inadequate (Alstone et al. 2010). Impaired visual performance (including disability glare) is, in turn, a risk factor in subsequent accidents and injuries. Similarly, inadequate illumination invites crime (Associated Press 2013; UNDP 2012; Peacock 2013).

Insufficient illumination can lead to poor visual performance, fatigue and eyestrain. Research is inconclusive on whether sustained, insufficient illuminance levels and eyestrain contribute to myopia (near-sightedness) (Kittle 2008; Gauna 2012). A study of households using solid cooking

\footnotetext{
10 Kerosene ingestion accounted for a considerable proportion of all pediatric admissions at state hospitals across South Africa, ranging from $5.5 \%$ to $16.5 \%$ of all admissions, with markedly higher rates (up to $78 \%$ ) in lower-income areas where kerosene is most widely used (Carolissen and Matzopoulos 2004).

${ }^{11}$ Recommended levels of illumination are based on laboratory and field studies of specific visual tasks and visual performance needs. They may also consider glare, fatigue and eye strain.

12 "Jharro is a resin rich oden stick from the high elevation Himalayan pine tree whose flame provides smoky but minimally adequate indoor lighting," according to Nepal's Rural Integrated Development Service. http://www.ridsnepal.org/index.php/Light.html
} 
fuels noted differences in cataract incidence depending on whether a home's light was provided by electricity or kerosene, with the risk twice as high for households using kerosene lighting (Pokhrel et al. 2005). The authors noted that the baseline incidence of cataracts is generally higher in developing countries and that more females than males are blind from cataracts, but there is no causal theory supporting a linkage with pollutants emitted during combustion. Cataract risks are wavelength-dependent, with ultraviolet being the most harmful, and, to a lesser degree, infrared. This author has not identified any studies that conclude that exposure to fuel-based lighting is a significant risk factor for cataracts.

In a recent set of interviews conducted by the author and colleagues, night fishermen in Tanzania reported multi-hour periods of reduced vision after each evening's handling of pressurized lanterns containing particularly bright mantles. Interviewers recorded self-reported claims of high incidence of blindness in old age (Mills et al. 2014). This purportedly resulted from repeated periods of close proximity to pressurized lanterns (which have 10 times the overall luminous output of typical wick lamps, from a mantle with very high luminosity). Eyestrain and poor eyesight attributed to glare and direct exposure to the luminance pressure lanterns are mentioned in other surveys conducted across sub-Saharan Africa (Baker and Alstone 2011).

Reliable, high-quality illumination is essential for the effective delivery of health services. Many facilities in the developing world operate only intermittently at night due to fuel availability and the inability to provide good care with only lanterns (Solar Aid 2012). Orosz et al. estimate that there are approximately 86,000 health clinics throughout the developing world that lack electricity, of which more than half are in Africa (2013). Studies note that lack of light discourages some in-need populations from even attempting to visit a clinic or hospital at night. Lack of electricity also presents challenges for keeping mobile phones charged, equipment sterile, and powering key tools for communicating with patients and staff. The cost of kerosene is a hardship for many healthcare providers.

\section{Disproportionate Impacts on Women and Children}

A consistent pattern that emerges from the available literature is that women and children bear the brunt of the health hardships associated with off-grid lighting (Alstone et al. 2011). For context, the rate of childhood unintentional injury deaths (from all causes) in the developing world is nearly four times that of the industrialized world, with 875,000 affected each year (Balan and Lingam 2012) and with millions more sustaining non-fatal injuries. Anecdotal reports suggest sexual violence against women is higher when in sufficient illumination is provided in public areas (Associated Press 2013; UNDP 2012; Peacock 2013).

The aforementioned problem of inadequate lighting in health clinics creates particular issues concerning maternal and infant health. Approximately 287,000 maternal mortalities occurred globally in 2010, 99\% of which occurred in developing countries (WHO 2012c). Two 2012 field studies document child delivery illuminated with kerosene lanterns or with light from makeshift, repurposed cell phones (Solar Aid 2012; Stachel 2012). In their analysis of the 
national household survey in India, Lakshmi et al. (2013) discovered an unexpectedly higher rate of stillbirths in women who rely on kerosene rather than electricity for lighting. An extensive study in India (Epstein et al. 2013) found lower infant birth rates and higher neo-natal mortalities were associated with households that used kerosene as a cooking fuel. It is not clear whether kerosene combustion for lighting would yield the same outcome.

As noted above, the issue of non-intentional fuel ingestion almost uniquely impacts children, especially infants and toddlers, and is typically the primary cause of child poisoning in the developing world.

Studies of lamp explosions due to fuel adulteration found up to two-fold higher impacts among children than adults: $62 \%$ versus $38 \%$ injury (Grange et al. 1988 ) and $57 \%$ versus $25 \%$ mortality (Ugburo et al. 2003). Female to male ratios were also higher in each of three studies providing such data (Table 2).

Lighting-related burn injury rates are higher for females and children across many studies (Balan and Lingam 2011), with one study finding a 3:1 ratio in India (Kumar et al. 2002). Functional, social, and psychological impairment due to burns has been identified as one of the most devastating causes of child injury. In a nationwide study for Bangladesh, in which 171,000 households were visited, rural children were found to have a four times greater incidence of burn than those in urban areas; and, kerosene lamps were responsible for $23 \%$ of burns sustained by infants and $11 \%$ for children aged one to four years (Mashreky et al. 2008). In the same study, burns were the fifth leading cause of illness among the children aged one to 17 years of age, and the third leading cause for children aged one to four. Particularly tragic fires such as one in Senegal (where at least 9 children died when a candle fell over) involve indentured children or orphans that were confined without an opportunity to escape (Nossiter 2013). Burns from all causes are reported as the leading cause of death among children in South Africa (Mrubata and Dhlamini 2008).

To the extent that women and children spend more time indoors than men-and that children are intrinsically more vulnerable to hazards-they are differentially exposed to indoor air quality, fire, and lamp-explosion risks. A study of 345 people in 55 Kenyan households found that children of each gender up to the age of four spend roughly equal times indoors. However, females in all other age groups spend between one and four hours more per day indoors than males do (Ezzati and Kammen 2002). Males spend less overall time indoors than these other groups. A major study of 4,612 individuals drawn from representative locations in Bangladesh found that infants spend the most time indoors: approximately 20 hours per day, declining to 16 hours per day for individuals up to the age of 60 . After age 60 females' time indoors returns to a level of nearly 20 hours per day, while time spent indoors by males increases only to 16.5 hours per day. All groups of females over the age of 12 spend more time indoors (1.4 to 3.2 hours more per day) than do males. The Bangladesh study concluded that "young children and poorly-educated women in poor households face [indoor air] pollution exposures from cooking that are four-times those for men in higher-income households organized by more highly educated women," with half of the effect due to income and half to age and gender (Dasgupta 
et al. 2004). Data indicating location by time of day (and use of lighting by time of day) would be needed to determine if lighting-related emissions exposures differ materially among these groups. Men and children not participating in cooking activities will receive a larger share of their indoor air pollution exposures from lamps.

\section{Alternatives to Fuel-based Lighting}

\section{Health benefits of introducing solar-LED lighting systems}

Substantial and diverse health and safety risks posed by fuel-based lighting can be reduced through the substitution of non-combustion lighting technologies (Kimemia et al., 2014). In addition to improved health outcomes are multiple benefits of addressing these risks. In particular, eliminating fuel-based light sources would also reduce poverty and deliver a significant reduction in greenhouse-gas emissions (Mills 2005), while supporting new forms of employment (Mills 2014c), and weaning governments of the burden of fuel subsidies that often exceed expenditures on healthcare (Mills 2014b).

Grid electrification programs have attempted to displace lighting fuels for decades, but in most places the rate of progress lags even the rate of population growth. In some parts of the world, particularly sub-Saharan Africa, the number of people using fuels for lighting is still increasing. A far more promising, affordable, and scalable approach for energy access is the use of smallscale solar or grid-charged LED lighting systems, many of which provide more, better, and safer light at a lower total cost of ownership (see Mills 2005). Many examples have been documented. ${ }^{13}$

Available accounts of benefits are based on end-user reports, rather than rigorous independent studies. A field study of 500 homes in the Philippines observed near complete elimination of reported health and injury issues following replacement of kerosene lanterns with gridindependent LED lanterns (Figure 3). ${ }^{14}$ A study of 209 households in Ghana found that a far higher rate $(89 \%)$ of households using only kerosene for lighting reported having blackened nostrils (from soot) in the mornings than those using a mix of kerosene and solar lighting (24\%)

\footnotetext{
${ }^{13}$ Numerous case studies are documented on LuminaNET: http://luminanet.org/page/field-projects-directory

${ }^{14}$ In this report, the shorthand term "LED lantern" is used to describe a broad category of lighting products that have emerged over the past decade. Common attributes are: high-efficiency "white" LED light sources; compactness and portability; a battery or other form of storage that allows grid-independent operation, charging either from dedicated renewable (typically solar 10 peak watts) power source or a temporary grid connection (as mobile phones are charged); a larger degree of affordability than first-generation fluorescent devices; and they are "plug-and-play", i.e., no need for professional installation. Within these broad criteria are found many variations including light output (level and directionality), charging time, battery life, and, the presence of secondary functions such as phone charging. Quality also varies widely and those considered viable alternatives to fuel-based lighting have high levels of performance and truth-in-advertising such as those recognized by the Lighting Global product quality assurance program. There is no consensus on terminology, and descriptors such as lamp, lantern, torch, light, and pico power will often be used to describe some or all of the products in this category.
} 
(Obeng et al. 2008). A survey of 500 homes in Uganda found an $88 \%$ reduction in burns and a 93\% reduction in house fires after receiving solar lanterns (Shell Foundation 2015).

(a

Health and Safety Indicators with and without Kerosene Lighting

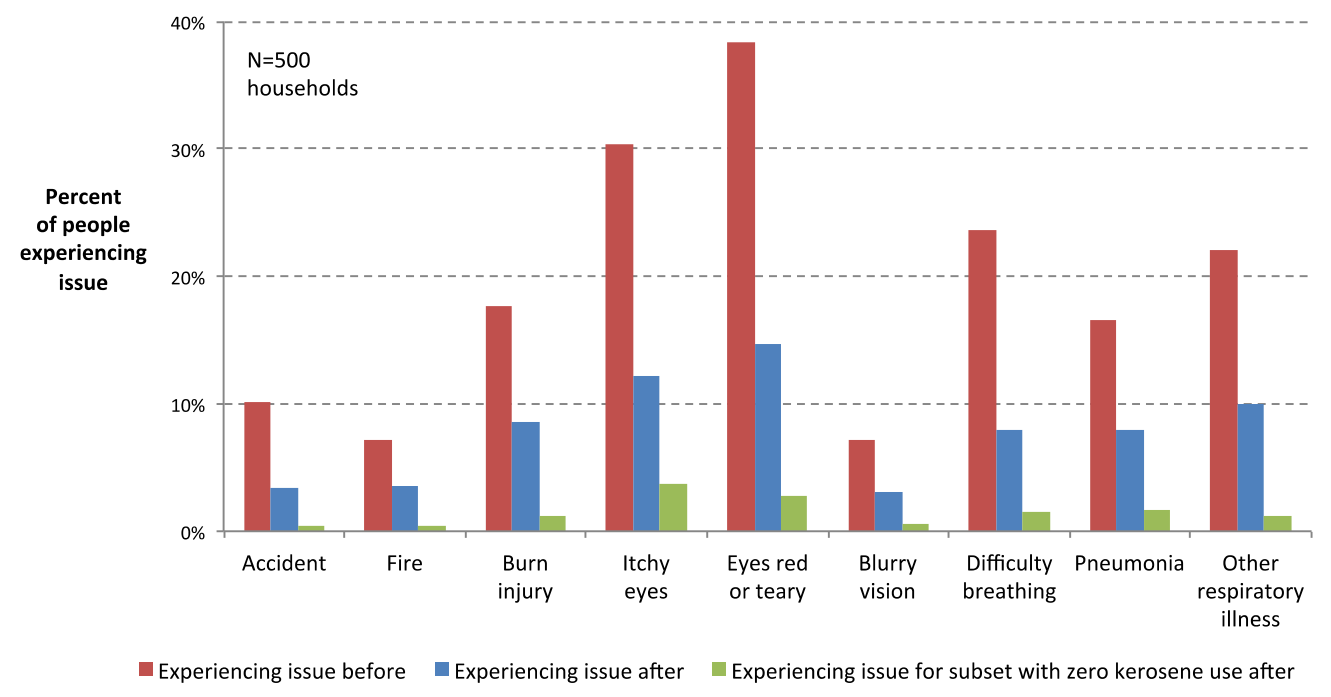

(b

The problems that have improved thanks to the kerosene consumption reduction:

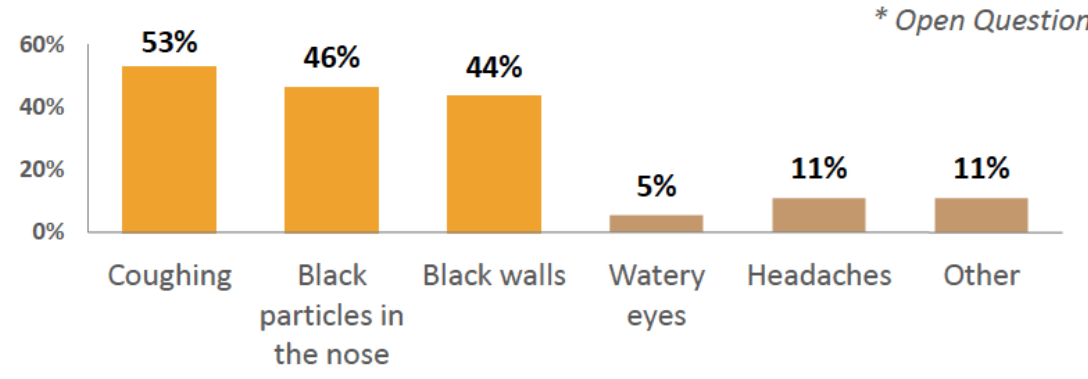

Figures $3 a$ and $3 b$. Data from Philippines. (a) Changes in user-reported health and safety problems believed to be associated with kerosene lanterns before and after receipt of LED-solar replacements among 500 homes in the Philippines (Thatcher 2012). Recipients were re-interviewed one month after receiving the fuel-free lamps. Note that $66 \%$ of the homes still used some kerosene after the intervention (blue bar). Symptoms were reduced much farther among the $27 \%$ of homes that completely eliminated kerosene use. (b) Separate study, 109 households reporting.

Refugee camps are particularly at risk for destructive fires caused by lanterns, as well as violence against women and children at night. For security and safety, lighting is an essential service. The UN High Commissioner on Refugees has initiated efforts to introduce solar lighting, with $60 \%$ of people reporting improved safety at night (UNDP 2012; UNHCR 2012).

Solar Aid installed 30 solar electricity and lighting systems in rural health facilities in Tanzania (Solar Aid 2012). Preliminary results found reduced rates of infection (including HIV); these outcomes were attributed to better illumination and associated ease of maintaining sanitation. Longer and more consistent operating hours reportedly induced more individuals to seek health care rapidly and more mothers to give birth in clinics. This improved access to services at night 
led to reduced patient waiting times during the day. Patients cited the benefit of not being expected to bring their own lantern and/or fuel to ensure treatment at night. The study claims a "clear increase" in safe baby deliveries at night, improved detection of postpartum hemorrhage, tears, or problems with the baby. Staff accounts indicated improved morale among hospital staff.

In a larger trial by Solar Aid, light was brought to clinics in Malawi, Tanzania, and Zambia that serve over 5,000 patients per month (Solar Aid 2011). Non-specific improvements to security and morale among workers and patients were reported to translate into a higher quality of service and better engagement of both staff and patients.

Nigeria has one of the highest maternal mortality rates in the world. One company has completed solar lighting installations at 26 Nigerian healthcare locations (along with power for cell phones and foetal monitors) (Stachel 2012). All locations reported a higher proportion of mothers coming to clinics for delivery, particularly night deliveries. Lighting provided particular benefits for complicated deliveries. Reliable illumination allowed for an increased rate of caesarean section surgeries to be performed at night. Blood bank procedures were also improved via increased ease and accuracy for testing the blood, together with refrigeration. Every site reported an improvement in health worker morale and willingness to come to work at night. Similar work was conducted in Sierra Leone, which has more than 1000 non-electrified rural clinics (Stachel 2013).

Health considerations of alternatives to fuel-based lighting

A switch to electric lighting is the most promising pathway for fully eliminating the risks associated with fuel-based light sources. Nonetheless, the generation and distribution of electricity are not risk-free, particularly when electricity is produced with fossil fuels or nuclear fission. Second-order issues such as the diversion of scarce water for power plant cooling and the concerns associated with electricity transmission lines should also be considered. Distributed renewable energy based generation mitigates most of these supply-related concerns.

Off-grid lighting systems based on renewable energy sources require some form of energy storage, typically batteries that can have associated health and safety risks. These end-use illumination devices may contain potentially harmful substances, for example, mercurycontaining lamps. From a lifecycle perspective, the environmental and health implications of the energy embodied in creating electric lighting systems must be considered. Solar-LED lanterns have been found to save far more energy than that embodied in their manufacture (Alstone et al., 2014).

First-generation electric off-grid lighting systems relied on large solar panels, large lead-acid batteries (used in a context in which there was rarely a process for recovery, recycling and reuse), and mercury-containing fluorescent lamps. Fortunately, the rapid transition in the past decade to highly miniaturized pico-photovolatic systems has dramatically reduced the physical 
amounts of materials involved as well as waste-management concerns. Mercury-containing lamps have been displaced by higher efficiency light emitting diode (LED) lamps. Due to reduced power requirements, the batteries and solar panels can be far smaller, with correspondingly lower materials inputs. The off-grid lighting product industry is making a rapid transition to lower environmental impact technology. For example, the share of lithium-ion batteries used in off-grid lighting products rose from 5\% in 2010 to $40 \%$ in 2012, while the shares of lead-acid batteries fell from $35 \%$ to $27 \%$ (Lighting Africa 2013).

New off-grid lighting products should be designed so that they do not compromise visual performance or health. For example, LED lanterns can be designed with shields to reduce glare. Commonly used low to mid-power white LEDs, the preferred light source for off-grid applications, are not regarded as eye safety risks (USDOE 2013). Most white LEDs do not emit ultraviolet or infrared radiation; however, blue wavelengths (in high color temperature lamps), if delivered with high power and intensity, can damage the retina. When a set of products geared for the off-grid market were tested using the IEC 62471 safety test protocol, one barely entered the "moderate risk" level after 58 seconds of exposure (Lighting Global 2013). This occurred under a worst-case test condition (holding the LED as close as possible to the eye while remaining in focus). These risks can be eliminated, and glare significantly reduced (and thus light quality increased), by utilizing a diffusing lens or material in front of the LED. Bluish light may also disrupt circadian rhythms, although this has not been attributed to LEDs thus far. LEDs are available that provide "warmer" (lower color temperature" illumination. While lowlight conditions can cause temporary eyestrain and perhaps nearsightedness over a long timeframe, off-grid LED systems will virtually always provide higher light levels than the flamebased products they replace. Care should be taken to develop minimum illuminance standards and best practice application guides for these products.

\section{Policy Strategies}

Fuel-based lighting is associated with a strikingly wide array of health and safety risks. The underlying drivers are many, with no single solution. Other authors have enumerated the causal factors, low levels of risk perception among at-risk populations, and available prevention strategies (Paraffin Safety Association 2004; Schwebel et al. 2009a-b; Mrubata and Dhlamini 2008; Swart and Bredenkamp 2012).

Approaches for better understanding the risks and reducing lighting-related injuries and loss of life can be grouped into the following broad categories.

More robust national-level baseline data on lighting fuel choices, using clearly defined and consistent definitions

- Baseline data are essential to identifying overall populations at risk, and the associated geographies. Better country-level data on the incidence of fuel-based lighting (including non-household contexts and among electrified populations) and the fuels used to do so 
are key needs. A particular information deficit includes the degree to which cooking fuels are used to provide light after cooking tasks are complete.

- Time-budget data are critical to understanding not only total hours spent indoors (important for assessing exposure to risks from cooking risks), but also what portion of that time is during hours where artificial lighting is in use.

- The degree of substitution achieved when electric alternatives are introduced is important information for determining residual risks where replacement technologies have been deployed.

More lab-based research on lighting technology characteristics

- Most testing of the emissions from fuel-based lighting equipment has focused on kerosene lamps. To this should be added diesel, animal and vegetable oils, dung, and fuel wood. Emissions from each will have unique chemical constituents and levels of particulates.

More rigorous and focused field-based epidemiological studies investigating risks and the potential benefits of alternatives

- The literature on this topic is new in the broader context of health and development research, and its quality is uneven. Systematic national or community-scale epidemiological information on lighting-related risks in the developing world is rare, with Ghana and South Africa making the greatest progress to-date in this respect. More centralized statistics should be gathered, per standardized methods, and used to better understand population-level risks.

- Moreover, most existing studies fail to separate lighting fuels from other sources of energy-related exposures and risk. A review of the relatively large body of literature on cooking-related risks may provide some lighting-related contextual information collected that would be useful. Van Vliet et al. (2013) provides one example of a study that gathered and analyzed such information.

- Several studies have tabulated user-reported reductions in symptoms or safety outcomes when solar-LED lighting has been introduced, but no scientifically rigorous assessments have been reported.

- Substantial and enduring mental and emotional injury may also result from lightingrelated accidents, adding to health costs, lost work time and lowered productivity, and replacing damaged homes and property. The literature does not systematically address such crucial impacts that follow the initial acute consequences arising from the off-grid lighting hazard. 
Improved consumer education, standards, and supporting energy policies

- Health and safety education is a critical need. For literate user groups (a subset of the overall population at risk), product labelling and other safety warnings could help reduce incidence of injury and death from fuel-based lighting. Other media, such as radio programs or in-person community health presentations, can also deliver safety information and introduce information about safer off-grid products. Such efforts, however, will not reach many populations.

- Although one in five people in the world are exposed to indoor pollution from fuelbased lighting on a daily basis, only World Health Organization guidelines exist for certain associated pollutants. Few national governments recognize that indoor air pollution is a public health concern that merits high priority. This gap must be bridged.

- Regulation and oversight of fuel handling, and more strict consequences for fuel adulteration, may reduce (but not eliminate) the life-threatening practice of mixing other fuels with kerosene. Energy price subsidy practices contribute to this problem, and thus subsidy reform is a tool for reducing this particular risk.

- Kerosene has long been subsidized and represented as a "clean" or "healthy" fuel when used instead of bio fuels. However, these subsidies undermine the cost-effectiveness of substituting non-combustion lighting systems, while extending kerosene supply for cooking purposes works as cross-purposes from eliminating it for lighting purposes.

\section{Transition to alternatives to fuel-based lighting, to reduce health and safety impacts}

- Any prospective change in lighting technology should be assessed in terms of health and safety risks. Combustion emissions, injury risk, and visibility-safety risks should all be assessed. Work is ongoing to assess the adequacy of illumination levels for poor populations who cannot afford lighting systems that replicate the levels of illumination expected by affluent societies.

- Cleaner-burning and shielded kerosene or propane lanterns are substantially more expensive to purchase and operate than standard exposed-wick lamps, further limiting their potential. Kerosene can be easily coloured to help distinguish it from water, but this precaution does not prevent ingestion by young children. Some organizations have promoted improved fuel-based lanterns (WHO and UNICEF 2008). This, however, addresses fire risk at best, while doing little to address indoor pollution, child poisoning by ingestion of fuel, fuel-adulteration hazards, and emissions of greenhouse gases.

- Fossil fuel-based lighting technologies can, to some extent, be re-engineered, for example, to reduce tip-over risks of lanterns, improve combustion efficiency, or eliminate lead from candle wicks. However, many fuel-based lighting devices are hand- 
manufactured using discarded metal or glass containers, severely limiting any affordable opportunity for a centralized solution.

\section{Conclusions and Recommendations}

The diverse morbidity and mortality risks of fuel-based lighting suggested by the literature include: burns (arising from structure fires as well as explosions from adulteration of kerosene with other fuels); health risks from indoor air pollution; poisoning from non-intentional ingestion of kerosene; compromised visibility and visual health; a variety of health and safety issues; and, adverse or suboptimal outcomes in health-service facilities illuminated solely or sporadically with fuel-based light. These impacts are experienced disproportionately by women and children.

Replacement of intrinsically dangerous fuel-based technologies with off-grid LED lanterns is the most promising way to eliminate the myriad risks of lighting fuels. It reduces the cost of lighting as well, thereby supporting broader goals to alleviate poverty. It is encouraging that a wide variety of effective and affordable technologies have recently emerged in the market. A host of policy strategies are being brought to bear to accelerate the uptake of these alternatives to fuel-based lighting. In addition to displacing hazardous lighting practices, these new technologies also enable the introduction of light into areas that are presently not lit at all, in turn enhancing safety in a variety of ways.

Policies and programs seeking the greatest possible benefit should target the most impacted geographical and demographic user groups. Examples include improved illumination in healthcare facilities, substitutes for kerosene lighting where housing is dense and poorly defended from fire (slums) and where fuel adulteration is particularly common due to fuel subsidy imbalances and other factors. Systems such as South Africa's mapping of fuel-related injuries could be emulated to deploy targeted programs for grid-independent electric lighting replacements for fuel-based lighting. Improved technologies for women and children will yield particularly significant health benefits.

\section{Acknowledgments}

This work was supported by the United Nations Environment Programme's en.lighten initiative in partnership with Germany's Federal Ministry for Economic Co-operation and Development (BMZ), to facilitate policy development in the Economic Community of West African States (ECOWAS) region, and by the Assistant Secretary for International Affairs of the U.S. Department of Energy under Contract No. DE-AC02-05CH11231. The following reviewers contributed data, time and expert insights: Peter Alstone and Nick Lam, (UC Berkeley); Martin Bachler, Leyla Kuhls and Gerhard Mair, (Osram); Kate Bliss; Johanna Diecker, (GOGLA); Gautam Dutt (International Energy Initiative); Kevin Gauna (Sunbrothers); James Irlam, (UCT); Arne Jacobson, (Humbolt State University); Darin Kingston, (d.light design); Bohzil Kondev, (GIZ); Caroline McGregor, (US Department of Energy); Dustin Poppendieck, (US Department of 
Commerce); David Schwebel, (University of Alabama Birmingham); Laura Stachel, (WeCare Solar); Russell Sturm, (IFC); Ibrahim Soumaila, (ECREEE); Dehran Swart; Shane Thatcher, (Illumination Headquarters Ltd); and, Kathryn Conway and Olola Vieyra, (UNEP).

\section{References}

Alstone, P. A. Jacobson, and E. Mills. 2010. "Illumination sufficiency survey techniques: in-situ measurements of lighting system performance and a user preference survey for illuminance in an off-grid, African setting." Lumina Project Research Note \#7 Retrieved from http://light.Ibl.gov/pubs/rn/lumina-rn7-illuminance.html [Accessed June 13, 2014]

Alstone, P. C. Niethammer, B. Mendonca, and A. Eftimie. 2011. "Expanding women's role in Africa's modern off-grid lighting market." Lighting Africa report. 34pp. Retrieved from http://www.esmap.org/sites/esmap.org/files/gender_lighting_highres_LOW\%20RES.pdf [Accessed July 22, 2014]

Alstone, P., P. Lai, E. Mills, and A. Jacobson. 2014. "High Life Cycle Efficacy Explains Fast Energy Payback for Improved Off-Grid Lighting in the Developing World." Journal of Industrial Ecology. http://evanmills.lbl.gov/pubs/pdf/Alstone-etal-2014-jie-c12117.pdf

American Cancer Society. 2006. “Cancer facts \& figures: 2006." Report 500806, Atlanta 52pp. Retrieved from http://www.cancer.org/acs/groups/content/@nho/documents/document/caff2006pwsecu redpdf.pdf [Accessed June 13, 2014]

Apple, J., R. Vicente, A. Yarberry, N. Lohse, E. Mills, A. Jacobson, and D. Poppendieck. 2010. "Characterization of particulate matter size distributions and indoor concentrations from kerosene and diesel lamps." Indoor Air 20 (5) 399-411 and Lumina Project Technical Report \#7 Retrieved from http://light.lbl.gov/pubs/tr/lumina-tr7-iaq.html [Accessed June 13, 2014]

Arthur, B.K. 2012. "Kerosene poisoning kills 1000s." The Finder. July 23.

Associated Press. 2000. "Fire destroys 1,500 huts in slums of Bangladesh." Retrieved from http://lubbockonline.com/stories/032600/wor_032600060.shtml [Accessed June 13, 2014]

Associated Press. 2013. "Somalia: Solar lights protect against sex attacks." September 2. Retrieved from http://bostonherald.com/news_opinion/international/africa/2013/09/somalia_solar_lights _protect_against_sex_attacks [Accessed July 22, 2014]

Asuquo, M.E., O. Ngim, and C. Agbor. 2008. "A prospective study of burn trauma in adults at the University of Calabar Teaching Hospital, Calabar (South Eastern Nigeria)." Open Access Journal of Plastic Surgery. Retrieved from http://www.eplasty.com/index.php?option=com_content\&view=article\&id=219\&catid=145 \&Itemid=121 [Accessed June 13, 2014]

Azizi, B.H.O., H.I. Zulfifli, and M.S. Kassim. 1994. "Circumstances surrounding accidental poisoning in children." Medical Journal of Malaysia, Vol. 49(2):132-137. Retrieved from 
http://www.e-mjm.org/1994/v49n2/Children_Accidental_Poisoning.pdf [Accessed June 13, 2014]

Babalola, A. and A. Ekiti. 2011. "Kerosene Adulteration in Nigeria: Causes and Effects," American Journal of Social and Management Science, 2(4): 371-376 http://www.scihub.org/AJSMS/PDF/2011/4/AJSMS-2-4-371-376.pdf [Accessed August 10, 2014]

Bai, N., Khazaei, M., Eden, S. and Laher, I. 2007. "The pharmacology of particulate matter air pollution-induced cardiovascular dysfunction" Pharmacology \& Therapeutics, 113, 16-29. Retrieved from http://www.ncbi.nlm.nih.gov/pubmed/16920197 [Accessed July 22, 2014]

Baker, M. and P. Alstone. 2011. "The off-grid lighting market in Sub-Saharan Africa: market research synthesis report." Lighting Africa, 91pp. Retrieved from http://light.lbl.gov/library/la-mkt-synthesis.pdf [Accessed July 22, 2014] Underlying data tables provided by the authors for further analysis.

Balan B. and L. Lingam. 2011. "Unintentional injuries among children in resource poor settings: where do the fingers point?" Archives of Disease in Childhood, doi: 10.1136/archdischild-2 of 4 2011-300589. Retrieved from http://adc.bmj.com/content/97/1/35.full.pdf+html [Accessed June 13, 2014]

Behera D., S. Dash, and S.P. Yadav. 1991. "Carboxyhemoglobin in women exposed to different cooking fuels". Thorax 46(5):344-346. Retrieved from http://www.ncbi.nlm.nih.gov/pmc/articles/PMC463132/ [Accessed July 22, 2014]

Belonwu, R.O. and S.I. Adeleke. 2008. "A Seven-Year Review of Accidental Kerosene Poisoning in Children at Aminu Kano Teaching Hospital, Kano." Nigeria Journal of Medicine 17(4):380382. Retrieved from http://www.ncbi.nlm.nih.gov/pubmed/19048749 [Accessed July 22, 2014]

Bernard, B. 2011. "Living with a 'monster."' The Source. Vol. 28, No. 19. February 28. Retrieved from http://www.thesourceng.com/MonsterFebruary282011.htm [Accessed June 13, 2014]

Bhusal, P., Zahnd, A., Eloholma, M., and Halonen, L. 2010. "Replacing fuel based lighting with light emitting diodes in developing countries: energy and lighting in rural Nepali homes." Leukos 3(4):277-291, April. Retrieved from http://light.lbl.gov/library/leukos-may07.pdf [Accessed July 22, 2014]

Birkenshaw, M. 2008. "A Big Devil in the Jondolos: The Politics of Shack Fires." 19pp. Retrieved from

http://www.academia.edu/2196824/A_Big_Devil_in_the_Jondolos_The_Politics_of_Shack_ Fires [Accessed July 22, 2014]

Carolissen, G. and R. Matzopoulos. 2004. "Paraffin ingestion.” In S. Suffla, A Van Niekerk and N. Duncan (Eds), Crime, Violence and Injury Prevention in South Africa: Developments and Challenges, Chapter 10, p.158 Tygerberg: MRC. Retrieved from http://www.unisa.ac.za/contents/faculties/humanities/shs/docs/CVI.pdf [Accessed July 22, 2014] 
Daily Independent. 2011. "Nigeria: kerosene explosion kills eight in Delta, Edo." February 5. Retrieved from http://allafrica.com/stories/201102071059.html [Accessed June 13, 2014]

Daily Mail. 2009. "Fire kills 16 people in the Philippines." November 2. Retrieved from http://www.metro.co.uk/news/world/760993-philippines-slum-fire-kills-16 [Accessed June $13,2014]$

Dasgupta, S., M. Huq, M. Khaliquzzaman, K. Pandey and D. Wheeler. 2006. "Who suffers from indoor air pollution? Evidence from Bangladesh." Health Policy and Planning, vol. 21, pp. 444-58. Retrieved from http://elibrary.worldbank.org/doi/pdf/10.1596/1813-9450-3428 [Accessed on July 22, 2014]

Dawson, Kevin. Private communication, July 15, 2013.

Dominici, F., McDermott, A., Zeger, S. and Samet, J. 2003. "Airborne particulate matter and mortality: timescale effects in four US cities." American Journal of Epidemiology, 157, pp. 1055-1065. Retrieved from http://www.ncbi.nlm.nih.gov/pubmed/12796040 [Accessed July $22,2014]$

Dongo, A.E., E.E. Irekpita, L.O. Oseghale, C.E. Ogbebor, C. E. Iyamu, and J.E. Onuminya, Sr. 2007. "A five-year review of burn injuries in Irrua." BMC Health Services Research 7:171. Retrieved from http://www.ncbi.nlm.nih.gov/pmc/articles/PMC2174937/ [Accessed July 22, 2014]

Epstein, M.B., M.N. Bates, N.K. Arora, K. Balakrishnan, D.W. Jack, and K.R. Smith. 2013. "Household fuels, low birth weight, and neonatal death in India: the separate impacts of biomass, kerosene, and coal." International Journal of Hygiene and Environmental Health, 215(5):523-532. Retrieved from http://ehs.sph.berkeley.edu/krsmith/publications/2012/2012_epstein.pdf [Accessed July $22,2014]$

Ezzati, M. and D. M. Kammen. 2002. "Evaluating the health benefits of transitions in household energy technologies in Kenya." Energy Policy, 30, pp. 815-826. Retrieved from https://mvsim.wikischolars.columbia.edu/file/view/Ezzati+and+Kammen+2002++Health+and+Houshold+Energy.pdf [Accessed July 22, 2014]

Fan, C. and Zhang, J. 2001. "Characterization of emissions from portable household combustion devices: particle size distributions, emission rates and factors, and potential exposures." Atmospheric Environment, 35, 1281-1290. Retrieved from http://www.sciencedirect.com/science/article/pii/S135223100000399X [Accessed July 22, 2014]

Fine, P.M., G.R. Cass, and B.R.T. Simoneit. 1999. "Characterization of fine particle emissions from burning church candles." Environmental Science \& Technology 33:2352-2362. Retrieved from http://www.researchgate.net/publication/231291544_Characterization_of_Fine_Particle_E missions_from_Burning_Church_Candles/file/9c96051e8191dd132d.pdf [Accessed July 22, 2014]

Fullerton, D. G., Jere, K., Jambo, K., Kulkarni, N. S., Zijlstra, E. E., Grigg, J., French, N., Molyneux, M. E. and Gordon, S. B. 2009. "Domestic smoke exposure is associated with alveolar 
macrophage particulate load." Tropical Medicine and International Health 14:349-354. Retrieved from http://www.ncbi.nlm.nih.gov/pubmed/19278528 [Accessed July 23, 2014]

Gad, S.C., and T. Pham. 2014. Encyclopedia of Toxicity, Elsevier.

Gauna, K. 2012. "Eco Design Notes: Issue 1: LED lights and eye safety." Lighting Global (in press). Retrieved from http://global-off-grid-lighting-association.org/wpcontent/uploads/2013/09/Issue_2_LEDLightsandEyeSafety_EcoNotes_final.pdf [Accessed July 23,2014$]$

Grange, A.O., A.O. Akinsulie and G.O.A. Sowemimo. 1988. "Flame burns disasters from kerosene appliance explosions in Lagos, Nigeria." Burns, 14(2):147-150 Retrieved from http://www.sciencedirect.com/science/article/pii/0305417988902239 [Accessed June 13, 2014]

Gupta, M., M. Bansal, A. Gupta, and P. Goil. 1996. "The kerosene tragedy of 1994, an unusual epidemic of burns: epidemiological aspects and management of patients." Burns, 22(1):3. Retrieved from http://www.ncbi.nlm.nih.gov/pubmed/8719308 [Accessed July 23, 2014]

IEA. 2014. "World energy outlook: 2014." International Energy Agency. Retrieved from http://www.worldenergyoutlook.org/publications/weo-2014/ [Accessed June 13, 2015]

Jayarama, V., K.M. Ramakrishnan and M.R. Davies. 1993. "Burns in Madras, India: an analysis of 1368 patients in 1 year." Burns 19(4):339-344. Retrieved from http://www.ncbi.nlm.nih.gov/pubmed/8357482 [Accessed July 23, 2014]

Kanchan T, R.G. Menezes, and F.N. Monteiro. 2009. "Fatal unintentional injuries among young children-a hospital based retrospective analysis." Journal of Forensic and Legal Medicine 16:307-11. Retrieved from http://www.ncbi.nlm.nih.gov/pubmed/19573838 [Accessed July $23,2014]$

Kimemia, D., C. Vermaak, S. Pachauri, and B. Rhodes. 2014. "Burns, scalds and poisonings from household energy use in South Africa: Are the energy poor at greater risk?" Energy for Sustainable Development 18:1-8. Retrieved from http://ac.elscdn.com/S0973082613001063/1-s2.0-S0973082613001063-main.pdf?_tid=1a3b2d5a-125311e4-95d2-00000aab0f27\&acdnat=1406111066_c225e7eeb8701d711b843f60baff92dd [Accessed July 23, 2014]

Kittle, J. 2008. "Reading in close-up settings will damage your vision-A myopic understanding?" Vanderbilt University, Department of Psychology. http://healthpsych.psy.vanderbilt.edu/2008/ReadingVision.htm [Accessed June 13, 2014]

Kumar, P., P. T. Chirayil, and R. Chittoria. 2000. "Ten years epidemiological study of paediatric burns in Manipal, India", Burns, 26:261-264. Retrieved from http://www.ncbi.nlm.nih.gov/pubmed/10741592 [Accessed July 23, 2014]

Lakshmi, P.V., N.K. Virdi, A. Sharma, J.P. Tripathy, K.R. Smith, M.N. Bates, and R. Kumar. 2013. "Household air pollution and stillbirths in India: analysis of the DLHS-II National Survey." Environmental Research, 121:17-22. Retrieved from http://www.ncbi.nlm.nih.gov/pubmed/23375552 [Accessed July 23, 2014] 
Lam, N. 2013. “Cigarette equivalents: Simple wick kerosene lamp." Prepared for Solar Aid, 6pp.

Lam, N. L., Chen, Y., Weyant, C., Venkataraman, C., Sadavarte, P., Johnson, M. A., Smith, K. R., Brem, B. T., Arineitwe, J., Ellis, J. E., and Bond, T. C. 2012a. "Household light makes global heat: High black carbon emissions from kerosene wick lamps." Environmental Science \& Technology, 46:13531-13538. Retrieved from

http://ehs.sph.berkeley.edu/krsmith/publications/2013/Lam_EST_12.pdf [Accessed July 23, 2014]

Lam, N.L., K. R. Smith, A. Gauthier, and M. N. Bates. 2012b. "Kerosene: A review of household uses and their hazards in low- and middle-income countries." Journal of Toxicology and Environmental Health, Part B: Critical Reviews, 15:6, 396-432. Retrieved from http://www.ncbi.nlm.nih.gov/pubmed/22934567 [Accessed July 23, 2014]

Lawal, Y.O. 2011. "Kerosene adulteration in Nigeria: causes and effects." American Journal of Social and Management Sciences 2(4):371-376 Retrieved from http://www.scihub.org/AJSMS/PDF/2011/4/AJSMS-2-4-371-376.pdf [Accessed July 23, 2014]

Legros, G, I. Havnet, N. Bruce, and S. Bonjour. 2009. "The Energy Access Situation in Developing Countries: A Review Focusing on the Least Developed Countries and Sub-Saharan Africa." World Health Organization and UNDP, 130pp. Retrieved from http://content.undp.org/go/cms-service/download/asset/?asset_id=2205620 [Accessed June 13, 2014]

Lighting Africa. 2013. "Lighting Africa market trends report 2012." 98pp. Retrieved from http://www.dalberg.com/documents/Lighting_Africa_Market_Trends_Report_2012.pdf [Accessed July 23, 2014]

Lim, S.S. 2013. "A comparative risk assessment of burden of disease and injury attributable to 67 risk factors and risk factor clusters in 21 regions, 1990-2010: a systematic analysis for the Global Burden of Disease Study 2010." Lancet, 380:2224-2260. Retrieved from http://ac.elscdn.com/S0140673612617668/1-s2.0-S0140673612617668-main.pdf?_tid=b261be26-125a11e4-971c-00000aab0f26\&acdnat=1406114327_ea60647aa39f973d85a9e88064b47eff [Accessed July 23, 2014]

Mashreky, S.R., A. Rahman, S.M. Chowdhury, S. Giashuddin, L. Svanstroem, M. Linnan, S. Shafinaz, I.J. Uhaa, and F. Rahman. 2008. "Epidemiology of childhood burn: yield of largest community based injury survey in Bangladesh." Burns, 34:856-862. Retrieved from http://www.ncbi.nlm.nih.gov/pubmed/18242869 [Accessed June 13, 2014]

Matzopoulos, R., E. Jordaan, and G. Carolissen. 2006. "Safety issues relating to paraffin usage in Eshane, KwaZulu-Natal." Journal of Energy in Southern Africa Vol 17 No 3: 4-7. Retrieved from www.erc.uct.ac.za/jesa/volume17/17-3jesa-matzopoulos.pdf [Accessed June 13, 2014]

Mills, E. 2005. "The specter of fuel-based lighting," Science, 308:1263-1264, 27 May. Retrieved from http://light.Ibl.gov/pubs/mills_science_fbl_full.pdf [Accessed July 23, 2014]

Mills, E. 2012. "Health impacts of fuel-based lighting: Working Paper," Presented at the 3rd International Off-Grid Lighting Conference, November 13-15, 2012, Dakar, Senegal. Lumina 
Project, Lawrence Berkeley National Laboratory. Retrieved from http://light.Ibl.gov/pubs/tr/Lumina-TR10-health-impacts.pdf [Accessed July 23, 2014]

Mills, E. 2014a. "Light for Life: Identifying and Reducing the Health and Safety Impacts of Fuelbased Lighting." Prepared for United Nations Environment Programme (UNEP) en.lighten initiative, Paris.

Mills, E. 2014b. "Lifting the Darkness on the Price of Light: Assessing the effect of subsidies for fuels in the off-grid lighting market in West Africa." [UNEP, forthcoming.]

Mills, E. 2014c. "Light \& Livelihood: A Bright Outlook for Employment in the Transition from Fuel-based Lighting to Off-grid Electric Alternatives." [UNEP, forthcoming.]

Mills, E. and N. Borg. 1999. "Trends in recommended lighting levels: an international comparison." Journal of the Illuminating Engineering Society of North America 28(1):155163. Retrieved from http://evanmills.lbl.gov/pubs/pdf/jies-1999-155-163.pdf [Accessed June 13, 2014]

Mills, E., Gengnegal, T., and P. Wolburg. 2014. "Solar-LED alternatives to kerosene lighting for night fishing," Energy for Sustainable Development, 21, pp. 30-41. Retrieved from http://evanmills.lbl.gov/pubs/pdf/night-fishing-esd.pdf [Accessed June 13, 2014]

Mmathabo, M., and T. Dhlamini. 2008. "A survey of paraffin users in Soweto to determine the impact of the removal of paraffin non-pressure stoves from the market." Prepared by AFRECA for the Programme for Basic Energy and Conservation (ProBEC).

NDMO. 2001. "Kerosene explosion disaster in Madang: Papau New Guinea." National Disaster Management Office. April 17. http://www.adrc.asia/counterpart_report/png010205.htm [Accessed July 23, 2014]

Nigerian News. 2011. "Explosion kills five in Port Harcourt." August 2. Retrieved from http://news2.onlinenigeria.com/headlines/70757-kerosene-explosion-kills-five-in-portharcourt.html [Accessed June 13, 2014]

Nisa, B.U., M. Ashfaq, and Y. Channa. 2010. "Kerosene oil ingestion among children presenting to the emergency department of a tertiary care paediatric hospital." Pakistan Paediatric Journal 34(2):65-69. Retrieved from http://www.ppa.org.pk/images/pdf/June_2010.pdf [Accessed July 23, 2014]

Nossiter, A. 2013. "Fire in Senegal Kills Child Beggars Trapped in House." New York Times, March 4. http://www.nytimes.com/2013/03/05/world/africa/fire-in-senegal-kills-childbeggars-trapped-in-house.html?_r=0 [Accessed June 13, 2014]

Obeng, G.Y., F.O. Akuffo, I. Braimah, H-D. Evers, and E. Mensah. 2008 "Impact of solar photovoltaic lighting on indoor air smoke in off-grid rural Ghana." Energy for Sustainable Development XII (1):9-65. Retrieved from http://ac.els-cdn.com/S0973082608604196/1s2.0-S0973082608604196-main.pdf?_tid=a7727dd8-125b-11e4-9caa00000aacb362\&acdnat=1406114739_a987b67f2e9318c4d6fb8efd41768edd [Accessed July 23, 2014] 
Oduwole, E.O., O.O. Odusanya, AO. Sani, and A. Fadeyibi. 1988. "Flame burns disasters from kerosene appliance explosions in Lagos, Nigeria." Burns, 14(2)147-150. Retrieved from http://www.ncbi.nlm.nih.gov/pubmed/3390735 [Accessed July 23, 2014]

Olaitan, P.B., S.O. Faidora, and O.S. Agodirin. 2007. "Burn injuries in a young Nigerian teaching hospital." Annals of Burns and Fire Disasters, XX (2):59-61. Retrieved from http://www.ncbi.nlm.nih.gov/pubmed/21991070 [Accessed July 23, 2014]

Oludiran, O.O., and P.F.A. Umebese. 2009. "Pattern and outcome of children admitted for burns in Benin City, mid-western Nigeria." Indian Journal of Plastic Surgery, Jul-Dec, 42(2):189193. Retrieved from http://www.ncbi.nlm.nih.gov/pubmed/20368855 [Accessed July 23, 2014]

Onoyume, J., S. Oyandongha, and E. Amaize. 2007. "Nigeria: Kerosine Explosion Kills 4 More in P-Harcourt," Vanguard August 6. http://allafrica.com/stories/200708060027.html [Accessed October 23, 2014]

Orosz, M.S., S. Quoilin, and H. Hemond. 2013. "Technologies for heating, cooling and powering rural health facilities in sub-Saharan Africa." Proceedings of the Institution of Mechanical Engineers, Part A: Journal of Power and Energy, 2013(227):717. Retrieved from http://pia.sagepub.com/content/early/2013/08/21/0957650913490300.full.pdf+html [Accessed July 23, 2014]

Osaghae, D.O. and G. Sule. 2013. "Socio-demographic Factors in Accidental Poisoning in Children." Journal of Medicine and Medical Sciences, 4(1):13-16. Retrieved from http://www.interesjournals.org/full-articles/socio-demographic-factors-in-accidentalpoisoning-in-children.pdf?view=inline [Accessed July 23, 2014]

Paraffin Safety Association. 2004. "Paraffin Safety Association Experts Forum final report." June 30. 92pp.

Paraffin Safety Association. 2012a. "Fast Facts." Retrieved from http://www.paraffinsafety.org/about/fast-facts/ [Accessed June 13, 2014]

Paraffin Safety Association. 2012b. "Candle use in South Africa: injuries \& impact." Briefing prepared by Sumaiyah Docrat.

Pattle, R.E. and H. Cullumbine. 1956. "Toxicity of some atmospheric pollutants." British Medical Journal, October 20, pp. 913-916. Retrieved from http://www.ncbi.nlm.nih.gov/pmc/articles/PMC2035479/ [Accessed July 23, 2014]

Peacock, L. 2013. "World Refugee Day: UN tests ground-breaking 'solar lighting' refugee camp shelters to keep women safer." The Telegraph, 20 June. http://www.telegraph.co.uk/women/womens-life/10130973/World-Refugee-Day-UN-testsground-breaking-solar-lighting-refugee-camp-shelters-to-keep-women-safer.html [Accessed June 13, 2014]

Pearson, K. 2011. "Kerosene, a burning issue in women's rights, human rights." [Blog post] http://lifelineenergy.org/kerosene-a-burning-issue-in-human-rights/ [Accessed June 13, 2014] 
Peck, M.D., G.E. Kruger, A.E. van der Merwe, W. Godakumbura, and R.B. Ahuja. 2008. "Burns and fires from flammable non-electric domestic appliances: Part 1. The Scope of the Problem." Burns, 34:303-311. Retrieved from http://www.worldburn.org/documents/burns_fires_domestic_appliances.pdf [Accessed July 23, 2014]

Planete d'Entrepreneurs. 2011."Stiftung Solarenergie \& Hybrid Social Solutions: Impact Assessment", 68pp. Retrieved from http://global-off-grid-lighting-association.org/wpcontent/uploads/2013/09/HSSi_Social_Impact_Assessment_PDE_Final_Report.pdf [Accessed July 23, 2014]

Pokhrel A.K., M.N. Bates, S.C. Verma, H.S. Joshi, C.T. Sreeramareddy, and K.R. Smith. 2010. "Tuberculosis and indoor biomass and kerosene use in Nepal: a case-control study." Environmental Health Perspectives, April, 118(4):558-64. Retrieved from http://www.ncbi.nlm.nih.gov/pmc/?term=10.1289/ehp.0901032 [Accessed June 13, 2014]

Pokhrel, A.K., K.R. Smith, A. Khalakdina, and A. Deuja, and M.N. Bates. 2005. "Case-control study of indoor cooking smoke exposure and cataract in Nepal and India." International Journal of Epidemiology, 34:702-708. Retrieved from https://nepalstudycenter.unm.edu/MissPdfFiles/AmodPokhcataractfinalNewsLet_Iss2_05_pdf.pdf [Accessed July 23, 2014]

Poppendieck, D. 2010. “Exposure to particulate matter from kerosene lamps." Presentation to the Lighting Africa conference, Nairobi, Kenya. Retrieved from http://lightingafricaconference.org/fileadmin/user_upload/Conference_2010/Day2/DAY2_P DF/Dustin_Poppendieck-Lighting_Africa_2010_-_Poppendieck.pdf [Accessed July 23, 2014]

Schare, S. and Smith, K.R. 1995. "Particulate emission rates of simple kerosene lamps." Energy for Sustainable Development, 2, 32-35. Retrieved from http://ehs.sph.berkeley.edu/krsmith/publications/keroseneemission.pdf [Accessed July 23, 2014]

Schwebel, D.C., D. Swart, J. Simpson, S.A. Hui, P. Hobe. 2009b. "Intervention to reduce kerosene-related burns and poisoning in low-income South African communities." Health Psychology, 28(4):493-500. Retrieved from http://www.ncbi.nlm.nih.gov/pubmed/19594274 [Accessed July 23, 2014]

Schwebel, D.C., D. Swart, S-kuen A. Hui, J. Simpson, and P. Hobe. 2009a. "Paraffin-related injury in low-income South African communities: knowledge, practice and perceived risk." Bulletin of the World Health Organization 87:700-706. Retrieved from http://www.who.int/bulletin/volumes/87/9/08-057505/en/index.html [Accessed June 13, 2014]

Shell Foundation. 2015. "Portfolio Overview: Shell Foundation's Current Access to Energy Partners." Published in Boiling Point, Issue 65, p36. http://www.hedon.info/BP65_ShellFoundationNews

Sharma S., Sethi G.R., Rohtagi A., Chaudhary A., Shankar R., Bapna J.S., et al. 1998. "Indoor air quality and acute lower respiratory infection in Indian urban slums." Environmental Health 
Perspectives, May, 106(5):291-297. Retrieved from

http://www.ncbi.nlm.nih.gov/pmc/articles/PMC1533083/ [Accessed July 23, 2014]

Shepherd, J.E. and F.A. 2007. "Kerosene lamps and cookstoves: the hazards of gasoline contamination." Fire Safety Journal, 43:171-179. Retrieved from http://www.sciencedirect.com/science/article/pii/S0379711207000835 [Accessed July 23, 2014]

Solar Aid. 2011. "The impact of solar on schools and clinics." 9pp.

Solar Aid. 2012. "Project evaluation report: Tanzania Health Facilities Program." 29pp.

Stachel, L. 2013. "Isha's Dream - Lighting up lives in Sierra Leone.” WeCare Solar, http://wecaresolar.org/ishas-dream-lighting-up-health-care-in-sierra-leone/ [Accessed June $13,2014]$

Statchel, L. 2012. Personal communication.

Statistics South Africa. 2012. Census 2011: Highlights of Key Results, 29pp. Retrieved from http://www.statssa.gov.za/Census2011/Products/Census_2011_Methodology_and_Highlig hts_of_key_results.pdf [Accessed July 23, 2014]

Swart, D. 2012. "Candle Use in South Africa: Injuries \& Impact." Presentation, WCDMC Seminar: Fire and Life Safety Strategies for Prevention - Informal Settlements. Retrieved from http://www.westerncape.gov.za/text/2013/March/strategies-to-address-householdenergy-injuries.pdf [Accessed June 21, 2014]

Swart, D. and B. Bredenkamp. 2012. "The challenge of addressing household energy poverty." Presented at Strategies to Overcome Poverty and Inequality Conference - Towards Carnegie III, University of Cape Town, South Africa, 11pp. Retrieved from http://www.carnegie3.org.za/docs/papers/258\%20THE\%20CHALLENGE\%200F\%20ADDRESS ING\%20HOUSEHOLD\%20ENERGY\%20POVERTY\%20\%28FINAL\%29.pdf [Accessed July 23, 2014]

Tamuno, T. 2012. "Eleven die in kerosene explosions." Daily Times. March 15. http://www.dailytimes.com.ng/article/eleven-die-kerosene-explosions [Accessed July 23, 2014]

Thaindian News. 2010. "200 slum dwellings gutted in Haryana fire." http://www.thaindian.com/newsportal/uncategorized/200-slum-dwellings-gutted-inharyana-fire_100362375.html [Accessed June 13, 2014]

Thatcher, S. 2012. "An empirical Study into the benefits of relieving energy poverty in the developing world." 2pp. Retrieved from http://www.pfpi.org/pdf/empiricalStudy_energy_poverty.pdf [Accessed July 23, 2014], plus data files (personal communication, September 23, 2012).

The Mercury. 2010. "Fire leaves two dead, 2000 homeless." July 5.

The Telegraph. 2011a. "One more dies in kerosene blast; Death toll rises to eight, 62 injured." July 31. Calcutta, India. 
http://www.telegraphindia.com/1110731/jsp/northeast/story_14311047.jsp [Accessed June 13, 2014]

The Telegraph. 2011b. "Report Finds Anomaly in Kerosene: Flash Point of Oil Sample Found below Normal 35 Degrees Censius," July 27. Calcutta, India. http://www.telegraphindia.com/1110727/jsp/northeast/story_1429 [Accessed June 13, 2014]

UCRI. 2010. “World Refugee Survey 2009: Nepal.” U.S. Committee for Refugees and Immigrants, http://www.refugees.org/resources/refugee-warehousing/archived-worldrefugee-surveys/2009-wrs-country-updates/nepal.html [Accessed June 13, 2014]

Ugburo, A., J.O. Oyeneyin, T.A. Atuk, I.S. Desalu, and G.A. Sowemimo. 2003. "The management of an epidemic flame burns disaster resulting from the explosion of kerosene appliances treated at the Lagos University Teaching Hospital, Nigeria." Annals of Burns and Fire Disasters XVI (3). Retrieved from http://www.medbc.com/annals/review/vol_16/num_3/text/vol16n3p115.asp [Accessed July 23, 2014]

UNDP. 2012. Award for Innovation.United Nations Office for South-South Cooperation, http://ssc.undp.org/content/ssc/services/expo/hall_of_fame/2012/innovation_award.html [Accessed June 13, 2014]

UNEP. 2013.Country Lighting Assessments. Retrieved from http://luminanet.org/page/countrydata-2\# [Accessed June 13, 2014]

UNHCR. 2012. "UNHCR project brings light, security and fuel-efficient cooking to refugees." 26 January. http://www.unhcr.org/4f21850e6.html [Accessed June 13, 2014]

United States Department of State. 1889. "Papers relating to the foreign relations of the United States, Transmitted to Congress, with the Annual Message of the President, December 3." Harvard Law Library, Received December 11, 1911. Retrieved from books.google.com/books?id=BI4LAAAAYAA [Accessed June 13, 2014]

US EPA. 2012. "Formaldehyde (CASNR 50-00-0)" U.S. Environmental Protection Agency, Integrated Risk Information System. http://www.epa.gov/iris/subst/0419.htm [Accessed June 13, 2014]

USDOE. 2013. "Optical safety of LEDs." U.S. Department of Energy, Solid State Lighting Technology Fact Sheet, PNNL-SA-96340. Retrieved from http://apps1.eere.energy.gov/buildings/publications/pdfs/ssl/opticalsafety_fact-sheet.pdf [Accessed June 13, 2014]

Van Niekerk, A., Van As, S. and Du Toit, N. 2004. "Childhood burn injury: epidemiological, management and emerging injury prevention studies." In S. Suffla, A Van Niekerk and N. Duncan (Eds), Crime, Violence and Injury Prevention in South Africa: Developments and Challenges, Chapter 9, pp.145-158. Tygerberg: MRC. Retrieved from http://www.unisa.ac.za/contents/faculties/humanities/shs/docs/CVI.pdf [Accessed July 23, 2014] 
VanVliet,E.D.S., K. Asante, D.W. jack, P.L. Kinney, R.M. Whyatt, S.N Chillrud, L. Abokvi, C. Zandoh, and S. Owusu-Agyei. 2013. "Personal exposures to fine particulate matter and black carbon in households cooking with biomass fuels in rural Ghana." Environmental Research, 127, November, pp. 40-48. Retrieved from http://dx.doi.org/10.1016/j.envres.2013.08.009 [Accessed June 13, 2014]

Wasson, S., Z. Guo, J. McBrian, and L. Beach. 2002. "Lead in candle emissions." Science of the Total Environment, 16 September, 296(1-3):159-174. Retrieved from http://www.sciencedirect.com/science/article/pii/S0048969702000724 [Accessed June 13, 2014]

World Health Organization and UNICEF. 2008. "World report on child injury prevention." M. Peden, K. Oyegbite, J. O-Smith, A.A. Hyder, C. Branche, A.K.M. Fazlur Rahman, F. Rivara, and K. Bartolomeos (eds.), 211 pp. Retrieved from http://whqlibdoc.who.int/publications/2008/9789241563574_eng.pdf [Accessed July 23, 2014]

World Health Organization. 2002a. "The injury chart book." United Nations, WHO, Department of Injuries and Violence Prevention, Non-communicable Diseases and Mental Health Cluster. Geneva. 80pp. Retrieved from http://whqlibdoc.who.int/publications/924156220x.pdf [Accessed July 23, 2014]

World Health Organization. 2006. "Air quality guidelines for particulate matter, ozone, nitrogen dioxide and sulphur dioxide - global update 2005." WHO/SDE/PHE/OEH/ 06.02. World Health Organization, Geneva, 20pp. Retrieved from http://www.who.int/phe/health_topics/outdoorair_aqg/en/[Accessed June 13, 2014]

World Health Organization. 2009. "Global health risks: mortality and burden of disease attributable to selected major risks." Geneva, World Health Organization, 62pp. Retrieved from http://www.who.int/healthinfo/global_burden_disease/GlobalHealthRisks_report full.pdf [Accessed June 13, 2014]

World Health Organization. 2012b. "Factsheet 365: Burns." http://www.who.int/mediacentre/factsheets/fs365/en/index.html [Accessed June 13, 2014]

World Health Organization. 2012c. "Trends in maternal mortality: 1990 to 2010." 59 pp. Retrieved from http://www.who.int/reproductivehealth/publications/monitoring/9789241503631/en/ [Accessed June 13, 2014]

Zai, S., H. Zhen, and W Jia-song. 2006. "Studies on the size distribution, number and mass emission factors of candle particles characterized by modes of burning." Aerosol Science, 37:1484-1496. Retrieved from http://www.sciencedirect.com/science/article/pii/S0021850206000899 [Accessed July 23, 2014] 
Zhang, J. and Smith, K.R. 2007. "Household air pollution from coal and biomass fuels in China: measurements, health impacts, and interventions." Environmental Health Perspectives, 115, 848-855. Retrieved from http://www.ncbi.nlm.nih.gov/pmc/articles/PMC1892127/

[Accessed July 23, 2014] 